Article

\title{
The Prevalence of Bartonella Bacteria in Cattle Lice Collected from Three Provinces of Thailand
}

\author{
Chulaluk Promrangsee ${ }^{1}$, Pathamet Khositharattanakool ${ }^{2}$, Puckavadee Somwang ${ }^{2}$, \\ Sakone Sunantaraporn ${ }^{3}$, Atchara Phumee ${ }^{4,5}$, Kanok Preativatanyou ${ }^{4}$, Apiwat Tawatsin ${ }^{6}$,
} Narisa Brownell ${ }^{4}$ and Padet Siriyasatien $4, *$ (])

1 Medical Parasitology Program, Department of Parasitology, Faculty of Medicine, Chulalongkorn University, Bangkok 10330, Thailand; famezaflamingoclub@hotmail.com

2 School of Medicine, Mae Fah Luang University, Chiang Rai 57100, Thailand; pathamet.kho@mfu.ac.th (P.K.); puckavadee.som@mfu.ac.th (P.S.)

3 Medical Science Program, Faculty of Medicine, Chulalongkorn University, Bangkok 10330, Thailand; narmspace_open@hotmail.com

4 Vector Biology and Vector Borne Disease Research Unit, Department of Parasitology, Faculty of Medicine, Chulalongkorn University, Bangkok 10330, Thailand; amphumee@gmail.com (A.P.); junior_science@windowslive.com (K.P.); natnarisa@gmail.com (N.B.)

5 Thai Red Cross Emerging Infectious Diseases-Health Science Centre, World Health Organization Collaborating Centre for Research and Training on Viral Zoonoses, Chulalongkorn Hospital, Bangkok 10330, Thailand

6 Department of Medical Sciences, Ministry of Public Health, National Institute of Health, Nonthaburi 11000, Thailand; atawatsin@gmail.com

* Correspondence: padet.s@chula.ac.th; Tel.: +66-22564387

Received: 30 April 2019; Accepted: 23 May 2019; Published: 28 May 2019

\begin{abstract}
Cattle lice are obligatory blood-sucking parasites, which is the cause of animal health problems worldwide. Recently, several studies have revealed that pathogenic bacteria could be found in cattle lice, and it can act as a potential vector for transmitting louse-borne diseases. However, the cattle lice and their pathogenic bacteria in Thailand have never been evaluated. In the present study, we aim to determine the presence of bacterial pathogens in cattle lice collected from three localities of Thailand. Total genomic DNA was extracted from 109 cattle louse samples and the Polymerase Chain Reaction (PCR) of $18 \mathrm{~S}$ $r R N A$ was developed to identify the cattle louse. Moreover, PCR was used for screening Bartonella spp., Acinetobacter spp., and Rickettsia spp. in cattle louse samples. The positive PCR products were cloned and sequenced. The phylogenetic tree based on the partial $18 S$ rRNA sequences demonstrated that cattle lice species in this study are classified into two groups according to reference sequences; Haematopinus quadripertusus and Haematopinus spp. closely related to $H$. tuberculatus. The pathogen detection revealed that Bartonella spp. DNA of gltA and rpoB were detected in 25 of 109 samples (22.93\%) both egg and adult stages, whereas Acinetobacter spp. and Rickettsia spp. were not detected in all cattle lice DNA samples. The gltA and $r p o B$ sequences showed that the Bartonella spp. DNA was found in both H. quadripertusus and Haematopinus spp. closely related to $H$. tuberculatus. This study is the first report of the Bartonella spp. detected in cattle lice from Thailand. The finding obtained from this study could be used to determine whether the cattle lice can serve as a potential vector to transmit these pathogenic bacteria among cattle and may affect animal to human health.
\end{abstract}

Keywords: cattle louse; Bartonella spp.; $18 \mathrm{~S}$ rRNA; gltA; rpoB; Thailand 


\section{Introduction}

Cattle lice are obligatory blood-sucking ectoparasites, which is an obstacle in the health and product performance of livestock [1]. Two major families of lice have been found on cattle; Haematopinidae family, including Haematopinus eurysternus, H. quadripertusus, H. tuberculatus and Linognatidae family; Linognathus vituli and Solenopotes capillatus [2]. Especially, the cattle tail blood-sucking louse, H. quadripertusus, is commonly found to infest on the cattle tail hair and is widespread in tropical and subtropical regions [3]. Lice infestation are a common cause of animal health and they can be responsible for economic losses by inducing pathophysiological changes in their hosts, including weight loss, skin infections and damage, loss of wool or hair due to scratching, and can cause mild to severe anemia [4]. In Thailand, the domestic cattle and buffaloes lice were reported in 18 provinces of central, eastern, northeastern and southern regions, which were identified as H. eurysternus, H. quadripertusus and L. vituli [5]. S. capillatus was first reported in Tak Province, Thailand by Changbunjong et al. (2009) [6]. The relevant information on pathogens in association with cattle lice, their hosts, geographic distribution, seasonality, and association with human or veterinary diseases is limited. Currently, several reports suggested that cattle lice are potentially vector of bacterial pathogens, including Bartonella spp. [7-9], Acinetobacter spp. [10], Rickettsia spp. [10,11], and Coxiella burnetii [11]. A study reported by Gutiérrez et al. (2014) demonstrated that Bartonella spp. infection in cattle lice; H. quadripertusus, and cattle blood from Israel. Moreover, $B$. bovis infection has been reported as a pathogen which causes endocarditis and bacteremia in cattle, and the $B$. henselae infection is the most common cause of cat scratch disease and presents systemic infection and with possible skin lesions in human [12]. The previous studies revealed that Rickettsia spp. were detected in Linognathus spp. and H. eurysternus from ruminants in Hungary [13,14]. Kumsa et al. (2012) showed that different Acinetobacter spp. could be found in L. vituli of cattle from the Oromia Regional State, Ethiopia [10]. Acinetobacter spp. in human head lice collected from school children in Thailand was also reported [15]. However, molecular techniques of cattle lice species and their pathogenic bacteria in Thailand have never been investigated. In this study, we demonstrated the use of molecular techniques for cattle lice species identification and detection of the potential bacterial pathogens in cattle louse samples collected from different areas of Thailand. Information obtained from the study provides fundamental data for the epidemiological study as well as the potential of cattle lice as a vector of zoonotic disease in Thailand.

\section{Materials and Methods}

\subsection{Collection of Lice from Beef Cattle}

The study was approved by the animal research ethics committee of Chulalongkorn University Animal Care and Use Protocol (CU-ACUP), Faculty of Medicine, Chulalongkorn University, Bangkok, Thailand (No. 005/2562). A total of 109 cattle lice samples consisted of 98 adults and 11 eggs. The collections were conducted in three different areas of Thailand, including Chiang Rai, Chiang Mai, and Nakhon Ratchasima provinces. Lice were manually collected from the hair tail and around the face of each cow. All specimens were preserved and surface decontaminated in $70 \%$ ethanol and transported to the Vector Biology and Vector Borne Disease Research Unit, Department of Parasitology, Faculty of Medicine, Chulalongkorn University. They were then classified to the genus level by morphological feature key $[16,17]$.

\subsection{DNA Extraction from Cattle Louse}

Genomic DNA was extracted from individual cattle louse, as follows. First, the louse was washed once in $1 \mathrm{~mL}$ of sterile $1 \mathrm{X}$ phosphate-buffer saline (PBS) for $5 \mathrm{~min}$ for removing the $70 \%$ ethanol, and then an individual cattle louse of each sample was homogenized in $200 \mu \mathrm{L}$ of lysis buffer $\mathrm{G}$ and $20 \mu \mathrm{L}$ of proteinase K. The genomic DNA was extracted using a DNA extraction kit, Invisorb ${ }^{\circledR}$ spin tissue mini kit (STRATEC molecular GmbH, Berlin, Germany) following the manufacturer's instructions. Finally, the extracted cattle lice DNA was obtained in $50 \mu \mathrm{L}$ of elution buffer. The genomic DNA was stored for long term at $-20^{\circ} \mathrm{C}$ until use in Polymerase Chain Reaction (PCR) amplification. 


\subsection{PCR for Cattle Louse Identification}

Conventional PCR was used for amplifying $18 S$ rRNA of the cattle louse. Degenerate oligonucleotide primers were designed based on $18 S$ rRNA sequences of the cattle lice obtained from GenBank database (GenBank: KJ522491 for H. quadripertusus, GU569180 for H. tuberculatus, HM171381 for H. eurysterunus, and AY077774 for Linognathus vituli) as forward primer 5'-CCGCGAAAGGCTCATTAAATCAG-3' , and the degenerate reverse primer sequences were $5^{\prime}$-CCTKCAATGGATACTCGTTAAATG-3' . The primers were synthesized by Bioneer Oligo Synthesis Report Company (Bioneer Corporation, Daejeon, Korea). PCR reaction was set up in the final volume of $25 \mu \mathrm{L}$ containing approximately $50 \mathrm{ng} / \mu \mathrm{L}$ of extracted DNA, $10 \mu \mathrm{M}$ of each primer, 10X Taq buffer, $2.5 \mathrm{mM}$ of dNTPs, $2.5 \mathrm{mM}$ of $\mathrm{MgCl}_{2}$ and 1 unit of Taq DNA polymerase (Thermo scientific, Waltham, MA, USA); double distilled water was as a negative control. PCR were performed under the following thermal cycling conditions: An initial denaturation step of $95^{\circ} \mathrm{C}$ for $3 \mathrm{~min}$, followed by 35 cycles of $95^{\circ} \mathrm{C}$ for $1 \mathrm{~min}, 58^{\circ} \mathrm{C}$ for $1 \mathrm{~min}$, and $72{ }^{\circ} \mathrm{C} 1.30 \mathrm{~min}$, with the final step of $72{ }^{\circ} \mathrm{C}$ for $7 \mathrm{~min}$ (Figure S1). The PCR amplicons were determined by $1.5 \%$ agarose gel electrophoresis, stained with ethidium bromide. The specific of PCR product were imaged under ultraviolet light with Quantity One Quantification Analysis Software version 4.5.2 (Gel DocEQ System; Bio-Rad, Hercules, CA, USA).

\subsection{Detection of Bacterial Pathogens in Cattle Louse DNA}

The cattle lice DNA were used to detect bacterial pathogens by using the PCR assay. The PCRs were performed using previously reported primers targeting the glt $A$ of Bartonella spp. [18], the rpoB of Acinetobacter spp. [19], and the gltA of Rickettsia spp. [20]. For the PCR reaction, $5 \mu$ of DNA template was used in a total volume of $25 \mu \mathrm{L}$; the reaction mixture contained 10X Taq buffer, $2.5 \mathrm{mM}$ of dNTPs, $2.5 \mathrm{mM}$ of $\mathrm{MgCl}_{2}, 10 \mu \mathrm{M}$ of each primer, and 1 unit of Taq DNA polymerase (Thermo scientific, Lithuania, EU). The PCR cycling conditions were as follows: Initial denaturation at $95^{\circ} \mathrm{C}$ for $3 \mathrm{~min}$; 35 cycles of $95^{\circ} \mathrm{C}$ for $30 \mathrm{~s}, 57,60$, and $55^{\circ} \mathrm{C}$ for Bartonella spp., Acinetobacter spp., and Rickettsia spp., for $30 \mathrm{~s}$ respectively, and $72{ }^{\circ} \mathrm{C}$ for $1 \mathrm{~min}$; and the final extension at $72{ }^{\circ} \mathrm{C}$ for $7 \mathrm{~min}$ (Figure S2). Positive and negative controls were included in each experiment. The PCR amplicons were confirmed by gel electrophoresis described above for louse. In order to confirm the species of the Bartonella bacteria, all DNA samples were detected by using conventional PCR amplification targeting a 406 bp fragment of RNA polymerase (rpoB) gene [21].

\subsection{DNA Cloning and Sequencing}

The positive PCR products were ligated into pGEM-T Easy Vector (Promega, Madison, WI, USA) using T4 DNA ligase. The DNA ligation was transformed into Escherichia coli DH5 $\alpha$ and screened using the blue-white colony selection system. The suspected positive colonies were cultured, and the plasmid DNA contained with the insert gene was isolated using the Invisorb ${ }^{\circledR}$ Spin Plasmid Mini Kit (STRATEC molecular GmbH, Berlin, Germany) following the manufacturer's instructions. Sequencing was performed by a commercial service in MACROGEN, Korea using a universal forward T7 primer.

\subsection{Sequence Analysis and Phylogenetic Tree Construction}

The nucleotide sequences were analyzed using the BioEdit Sequence Alignment Editor Version 7.2.5 [22]. The consensus sequences were analyzed by comparison with the nucleotide sequence in the GenBank database using BLAST search (https://blast.ncbi.nlm.nih.gov/Blast.cgi) and all the nucleotide sequences from this study were submitted to the GenBank database. The phylogenetic trees were constructed using the maximum-likelihood method with IQ-TREE on the IQ-TREE web server (http://iqtree.cibiv.univie.ac.at/) with 1000 ultrafast bootstrap replicates. The best-fit model of substitution was found using the auto function on the IQ-TREE web server [23]. The phylogenetic tree was finally viewed and edited with the FigTree v1.4.4 software. 


\section{Results}

\subsection{Morphology and Molecular Identification of Cattle Lice}

A total of 109 (11 eggs, 98 adults) cattle lice samples were collected from Chiang Mai (11 eggs, 88 adults), Chiang Rai (7 adults) and Nakhon Ratchasima (3 adults). The morphological characters to identify the species of adult stage cattle lice, showed H. quadripertusus $(n=95)$ and Haematopinus spp. $(n=3)$; whereas, the species of cattle louse egg was unable to be morphologically identified. The molecular technique, PCR based on the partial $18 S$ rRNA was developed to identify the cattle louse in Thailand. The portion of $18 S$ rRNA sequence was 745-746 bp. The results found 98 (7 eggs, 91 adults) samples clustered together with $H$. quadripertusus and 11 (4 eggs, 7 adults) samples of Haematopinus spp. closely related to $H$. tuberculatus with short branch lengths, which were identified by the phylogenetic tree base on the $18 S$ rRNA. (Table 1 and Figure 1). Sequence divergence was $0.2-2.9 \%$ between $H$. quadripertusus and Haematopinus spp. closely related to H. tuberculatus and 0.8-1.5\% between Haematopinus spp. closely related to $H$. tuberculatus and $H$. tuberculatus. The nucleotide sequences of $18 S$ rRNA of cattle lice were submitted to the GenBank database, accession numbers MK734185-MK734293 (Table S1).

Table 1. Cattle lice samples collected from three different areas of Thailand.

\begin{tabular}{|c|c|c|c|c|c|c|}
\hline \multirow{3}{*}{ Provinces } & \multicolumn{2}{|c|}{ Sample No. (n) } & \multicolumn{4}{|c|}{$\begin{array}{l}\text { Molecular Identification of Cattle Lice } \\
\qquad(18 S r R N A)\end{array}$} \\
\hline & \multirow[t]{2}{*}{ Egg } & \multirow[t]{2}{*}{ Adult } & \multicolumn{2}{|c|}{ H. quadripertusus (n) } & \multicolumn{2}{|c|}{$\begin{array}{c}\text { Haematopinus spp. Closely Related to } \\
\text { H. tuberculatus (n) }\end{array}$} \\
\hline & & & Egg & Adult & Egg & Adult \\
\hline Chiang Mai & 11 & 88 & 7 & 88 & 4 & NA \\
\hline Chiang Rai & NA & 7 & NA & NA & NA & 7 \\
\hline Nakhon Ratchasima & NA & 3 & NA & 3 & NA & NA \\
\hline \multirow{2}{*}{ Total } & 11 & 98 & 7 & 91 & 4 & 7 \\
\hline & \multicolumn{2}{|c|}{109} & \multicolumn{2}{|c|}{98} & \multicolumn{2}{|c|}{11} \\
\hline
\end{tabular}

NA: Not available. 


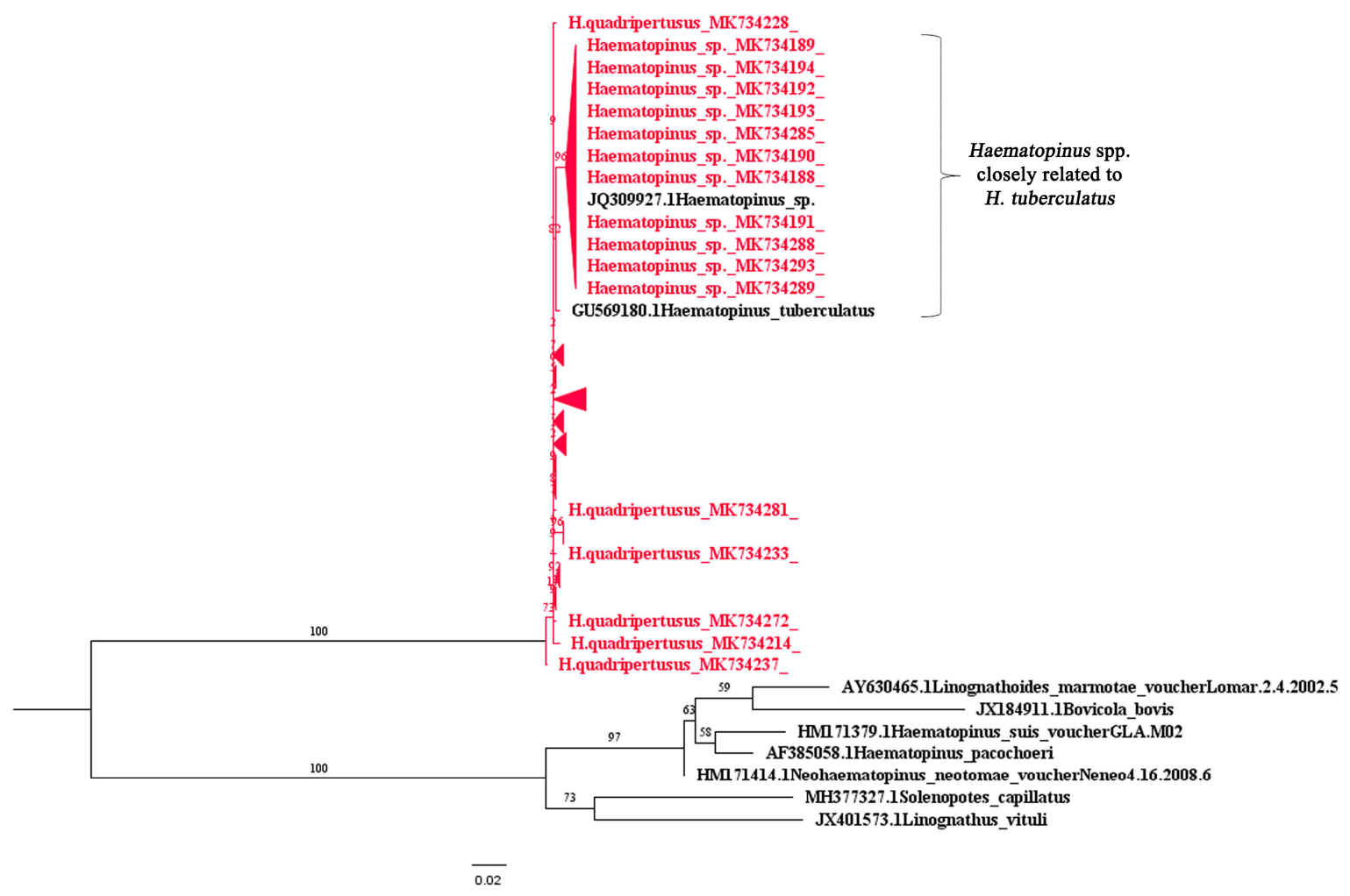

Figure 1. Phylogenetic tree of cattle lice constructed from partial $18 S \mathrm{rRNA}$ sequences. The maximum likelihood was constructed with IQ-TREE by using the maximum-likelihood method with 1000 ultrafast bootstrap replicates. The best-fit model of substitution was found using the auto function on the IQ-TREE web server. The sequences from this study are indicated with a red color.

\subsection{Detection of Bacterial Pathogen in Eggs and Adults Cattle Louse}

In this study, we investigated the PCR of all 109 cattle lice DNA for Bartonella spp., Acinetobacter spp. and Rickettsia spp. Only Bartonella spp. DNA was detected in 25 of 109 (22.93\%) samples. The positive samples including three egg samples and 22 adult samples. Bartonella spp. DNA was detected by PCR targeting the gltA in 22 of 98 (22.45\%) of H. quadripertusus collected from Chiang Mai (2 eggs, 17 adults) and Nakhon Ratchasima ( 3 adults). The Haematopinus spp. closely related to H. tuberculatus was detected in three of 11 (27.27\%) Bartonella spp. DNA from Chiang Mai (one egg) and Chiang Rai (two adults). One hundred and nine of cattle lice were also confirmed by PCR using primers targeting a $406 \mathrm{bp}$ fragment of the $r p o B$. The results showed 25 samples were positive for the Bartonella spp. DNA, which were the same samples positive for gltA (Table 2). The phylogenetic of Bartonella spp. of gltA (Figure 2A) and $r p o B$ (Figure $2 \mathrm{~B}$ ) from cattle louse were closely related to the $B$. bovis. The partial nucleotide sequence of the glt $A$ and $r p o B$ obtained in this study was deposited in the GenBank under accession number: MK748474-MK748498 and MK762880-MK762904, respectively (Table S2). 
Table 2. Molecular detection of Bartonella spp. DNA of $g l t A$ and $r p o B$ from cattle lice samples collected from three different areas of Thailand.

\begin{tabular}{ccccc}
\hline \multirow{2}{*}{ Provinces } & \multicolumn{3}{c}{ H. quadripertusus (n) } & \multicolumn{2}{c}{$\begin{array}{c}\text { Haematopinus spp. Closely Related to } \\
\text { H. tuberculatus (n) }\end{array}$} \\
\cline { 2 - 5 } & Egg & Adult & Egg & Adult \\
\hline Chiang Mai & $2 / 7$ & $17 / 88$ & $1 / 4$ & NA \\
Chiang Rai & NA & NA & NA & $2 / 7$ \\
Nakhon Ratchasima & NA & $3 / 3$ & NA & NA \\
\hline \multirow{2}{*}{ Total } & $2 / 7$ & $20 / 91$ & $1 / 4$ & $2 / 7$ \\
\cline { 2 - 5 } & & & $25 / 109$
\end{tabular}

Number: Positive/Total sample tested; NA: Not available.

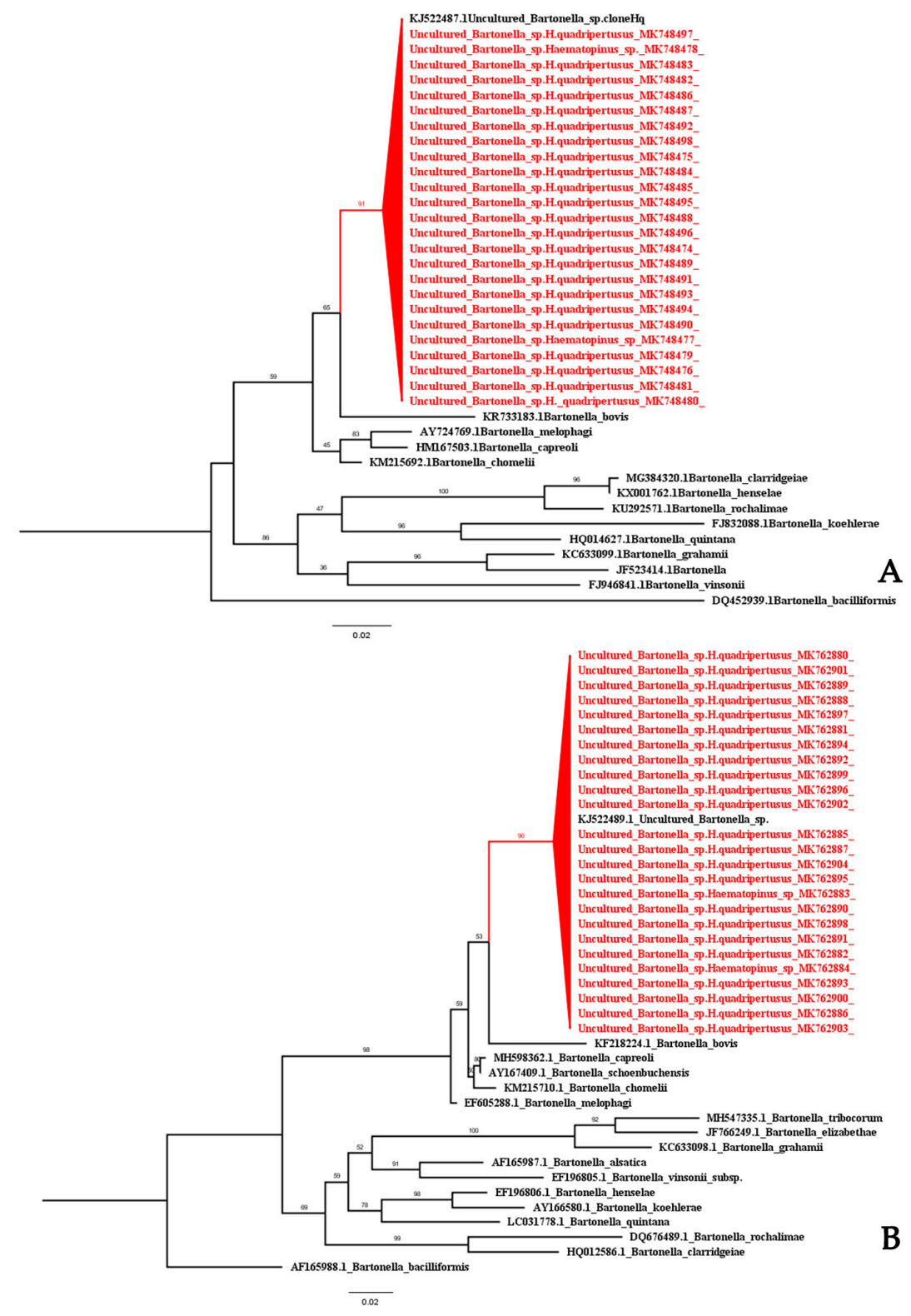

Figure 2. Phylogenetic tree of Bartonella spp. from cattle lice based on partial gltA (A) and rpoB (B) regions. The maximum likelihood was constructed with IQ-TREE by using the maximum-likelihood method with 1000 ultrafast bootstrap replicates. The best-fit model of substitution was found using the auto function on the IQ-TREE web server. The sequences from this study are indicated with a red color. 


\section{Discussion}

In Thailand, the identification of cattle louse is based on morphological characters. The precise identification depends on various factors such as stage of the louse samples and the experience of entomologist. Adult stages can be identified more accurately by morphology. However, it may lead to misidentification in case of immature stages such as eggs and nymphs of the cattle lice. As previously mentioned, the identification of cattle lice in Thailand has been based only on morphological characters which could be quite problematic. In order to solve this problem, we demonstrated the use of $18 \mathrm{~S}$ rRNA-PCR to identify the cattle lice species. To the best of our knowledge, this is the first molecular identification of cattle lice in Thailand. The phylogenetic analysis of $18 S \mathrm{SRNA}$ sequence of cattle louse revealed that $H$. quadripertusus was similar to the H. quadripertusus from Israel (Accession no. KJ522491) [12]. The Haematopinus spp. in this study showed similar to Haematopinus sp. NKU-011 from China (Accession no. JQ309927) [24] and clustered together with H. tuberculatus from Japan (Accession no. GU569180) [25]. Thereby, we assumed that the Haematopinus spp. in this study were Haematopinus spp. closely related to $H$. tuberculatus. The previous studies of domestic cattle and buffaloes lice in Thailand reported that H. eurysternus, H. quadripertusus, L. vituli, and S. capillatus were found by using taxonomic identification [5,6]. This preliminary study of phylogenetic tree of 109 cattle louse samples in three regions of Thailand revealed the genetic diversity among the louse samples. However, according to the limitation of information on the molecular evolution as well as sequences data for cattle lice in Thailand, we are not able to compare our results with other studies within the country. Several studies described that both mitochondrial (Cytochrome C oxidase subunit I: COI) [26] and nuclear genes (18S $r R N A$ and $E F-1 \alpha)[10,26]$ have been used to study the genetic diversity among cattle lice species. In this present study, the $18 S$ rRNA was selected because this gene has been previously used as an effective tool to demonstrate the evolution [26] and phylogeny of sucking lice [27]. Moreover, there are 18S $r R N A$ reference sequences of cattle lice available in GenBank more than other gene regions, which are also used for designing new primers in our study. As a result of this study, data of the 18S rRNA sequences of the 109 cattle louse samples from Thailand are already deposited in the GenBank.

In order to determine whether pathogenic bacteria could be found in the cattle lice, we performed the PCR assays for Bartonella spp., Acinetobacter spp., and Rickettsia spp. detections. The results showed that Acinetobacter spp. and Rickettsia spp. DNA were not detected in this study. Interestingly, 25 of 109 Bartonella spp. DNA was detected by both primer sets which annealed specially to the glt $A$ and $r p o B$ genes. Bartonella spp. DNA was found in both $H$. quadripertusus and closely related to H. tuberculatus. The glt $A$ and $r p o B$ sequences of Bartonella spp. are closely related to uncultured Bartonella spp. clone $\mathrm{Hq}$ in the cattle tail louse, H. quadripertusus Accession no. KJ522487 and KJ522489 from Israeli dairy farms, respectively [12]. In addition, $g l t A$ and $r p o B$ sequences of Bartonella spp. closely relate to the B. bovis strain I724598 from cattle blood in Malaysia (Accession no. KR733183) [28] and water buffalo blood in Thailand (Accession no. KF218224) [29]. The Bartonella bacteria are facultative intracellular bacteria that can be found in a wide range of mammalian and arthropods such as ticks, lice, fleas, and sand flies [30]. Cattle are currently claimed to be reservoirs of three Bartonella species including B. bovis, B. schoenbuchensis, and B. chomelii, however, none of these has been reported as causative agent in humans [31]. There are some reports that the infected arthropods could transmit Bartonella bacteria to human and other mammalian hosts such as $B$. henselae from cat fleas (Ctenocephalides felis) and B. quintana from human body lice (Pediculus humanus) [32,33]. The prevalence of Bartonella spp. isolated from a large number of rodents and shrews blood were found in several countries in Southeast Asia including Lao PDR (11.9\%), followed by Thailand (11\%) and Cambodia (9.6\%) [34]. In Thailand, many studies suggested the Bartonella spp. were detected in a febrile illness as well as endocarditis in patients and their potential animal reservoirs [35,36]. Bai et al. (2013) revealed that the Bartonella spp. was isolated from $10 \%(4 / 40)$ of the healthy cattle and B. bovis were cultured in $6.8 \%(7 / 103)$ from water buffaloes blood in Thailand [29]. However, data on cattle associated with the Bartonella infection in humans is still limited in Thailand. In the literature, high prevalence of Bartonella DNA and genotype diversity have been detected among arthropod vectors around the world. For example, the prevalence 
of B. bovis in cattle has shown variability, with reports from Italy (24.2\%) [37], France (59\%) [38], and Poland (6.8\%) [39]. In the United States, the B. bovis infection rates in cattle varied across the regions studied, being as high as $81-96 \%$ in California [7], 82.4\% in North Carolina [40] and less pronounced in Georgia (47\%) [41].

In terms of how these arthropods got infected with the bacterial pathogens remains unknown. Some authors suggested the possibility of either acquired infection from animal reservoirs or environmental contamination [10]. The bacterial pathogens could be transmitted among the arthropods through vertical transmission, mating, co-feeding, and fecal exposure. The finding of Bartonella spp. in both eggs and adult cattle lice in our study emphasized the possibility of vertical transmission of bacterial pathogen among these arthropods.

This is the first evidence of the discovery of the Bartonella spp. DNA in cattle lice in Thailand and detection of the Bartonella spp. DNA in eggs of the lice suggested that the vertical transmission of the bacteria in arthropods may occur. Despite the previous negative relation of cattle-associated Bartonella spp. causing diseases in human, there is still the feasibility that these bacteria might play a role in zoonotic infection among humans through the bite of blood-sucking insects in the ranch, or accidental contact with infected animals blood via skin abrasion. Further studies are needed to confirm the aforementioned hypothesis. Other blood-sucking arthropods in dairy farms should be targeted in future studies to clarify the potential role of these arthropods as the vectors in the life cycle of the cattle-associated Bartonella spp. Regarding the limitations of the study, the number of collected cattle lice were quite low in some regions of Thailand. This could be due to the increased use of insecticides in modern dairy farms to get rid of the cattle lice in order to keep the cattle healthy and hygienic.

\section{Conclusions}

Our findings demonstrated the first use of molecular techniques for the identification of cattle lice species and also showed that Bartonella species can be found in cattle lice collected from three regions of Thailand. Both H. quadripertusus and Haematopinus spp. closely related to $H$. tuberculatus could be the vectors of Bartonella spp. Further studies including extensive surveys and more precise studies of cattle lice covering more areas and larger sample sizes must be performed in order to understand the geographical distribution of cattle lice in the country. Moreover, the Bartonella spp. prevalence from cattle lice and cattle blood in other locations in Thailand should be investigated to determine the role of domestic animals as the potential sources for human and animal bartonellosis in Thailand.

Supplementary Materials: The following are available online at http://www.mdpi.com/2075-4450/10/6/152/s1. Figure S1: $18 S$ rRNA-PCRs for cattle louse identification; Figure S2: PCRs for Bartonella spp. Detection; Table S1: Accession numbers of DNA sequences deposited in GenBank for the $18 S r R N A$ of cattle lice detected in this study; Table S2: Accession numbers of DNA sequences deposited in GenBank for the gltA and rpoB of Bartonella sp. detected in this study.

Author Contributions: Conceptualization, P.S.; Methodology, C.P.; Software, C.P. and S.S.; Validation, P.S., C.P. and S.S.; Formal analysis, P.S.; Investigation, P.K., P.S.W., and A.T.; Resources, P.S.; Data curation, P.S., and K.P.; Writing-original draft preparation, C.P. and S.S.; Writing-review and editing, P.S., N.B. and A.P.; Visualization, P.S.; Supervision, P.S.; Project administration, C.P.; Funding acquisition, P.S.

Funding: This study was supported by the Rachadapisaek Sompote Fund, Faculty of Medicine, Chulalongkorn University (Grant No. RA 62/067).

Acknowledgments: We appreciated the staff of Vector Biology and Vector Borne Disease Research Unit, Department of Parasitology, Faculty of Medicine, Chulalongkorn University, Thailand and School of Medicine, Mae Fah Luang University, Chiang Rai, Thailand.

Conflicts of Interest: The authors declare no conflict of interest. 


\section{References}

1. Byford, R.L.; Craig, M.E.; Crosby, B.L. A review of ectoparasites and their effect on cattle production. J. Anim. Sci. 1992, 70, 597-602. [CrossRef]

2. Kumsa, B.; Bekele, S. Lice Infestation on Cattle in Endegagn District, Southern Ethiopia: Species Composition, Prevalence and Seasonal Pattern. Bull. Anim. Health Prod. Afr. 2008, 56, 213-222. [CrossRef]

3. Durden, L.A.; Loyd, J.E. Lice (Phthiraptera). In Medical and Veterinary Entomology, 2nd ed.; Mullen, G.R., Durden, L.A., Eds.; Academic Press Ltd.: London, UK, 2009; pp. 59-82.

4. Taylor, M.A.; Coop, R.L.; Wall, R.L. Parasites of horses. In Veterinary Parasitology, 3rd ed.; Taylor, M.A., Coop, R.L., Wall, R.L., Eds.; Blackwell Publishing: Oxford, UK, 2007; pp. 259-315.

5. Sangvaranond, A. Studies on lice of domesticated cattle and buffaloes in Thailand. J. Thai. Vet. Med. Assoc. 1988, 39, 165-174.

6. Changbunjong, T.; Buddhirongawatr, R.; Suwanpakdee, S.; Siengsanan, J.; Yongyuttawichai, P.; Cheewajorn, K.; Jangjaras, J.; Sangloung, C.; Ratanakorn, P. A survey of ectoparasitic arthropods on domestic animals in Tak Province, Thailand. Southeast Asian J. Trop. Med. Public Health 2009, 40, 435-442. [PubMed]

7. Chang, C.C.; Chomel, B.B.; Kasten, R.W.; Heller, R.M.; Ueno, H.; Yamamoto, K.; Bleich, V.C.; Pierce, B.M.; Gonzales, B.J.; Swift, P.K.; et al. Bartonella spp. isolated from wild and domestic ruminants in North America. Emerg. Infect. Dis. 2000, 6, 306-311. [CrossRef]

8. Maillard, R.; Riegel, P.; Barrat, F.; Bouillin, C.; Thibault, D.; Gandoin, C.; Halos, L.; Demanche, C.; Alliot, A.; Guillot, J.; et al. Bartonella chomelii sp. nov., isolated from French domestic cattle (Bos taurus). Int. J. Syst. Evol. Microbiol. 2004, 54, 215-220. [CrossRef]

9. Rolain, J.M.; Rousset, E.; La Scola, B.; Duquesnel, R.; Raoult, D. Bartonella schoenbuchensis isolated from the blood of a French cow. Ann. N. Y. Acad. Sci. 2003, 990, 236-238. [CrossRef]

10. Kumsa, B.; Socolovschi, C.; Parola, P.; Rolain, J.M.; Raoult, D. Molecular detection of Acinetobacter species in lice and keds of domestic animals in Oromia Regional State, Ethiopia. PLoS ONE 2012, 7, e52377. [CrossRef] [PubMed]

11. Reeves, W.K.; Szumlas, D.E.; Moriarity, J.R.; Loftis, A.D.; Abbassy, M.M.; Helmy, I.M.; Dasch, G.A. Louse-borne bacterial pathogens in lice (Phthiraptera) of rodents and cattle from Egypt. J. Parasitol. 2006, 92, 313-318. [CrossRef]

12. Gutiérrez, R.; Cohen, L.; Morick, D.; Mumcuoglu, K.Y.; Harrus, S.; Gottlieb, Y. Identification of different Bartonella species in the cattle tail louse (Haematopinus quadripertusus) and in cattle blood. Appl. Environ. Microbiol. 2014, 80, 5477-5483. [CrossRef]

13. Hornok, S.; de la Fuente, J.; Biro, N.; Fernandez de Mera, I.G.; Meli, M.L.; Elek, V.; Gönczi, E.; Meili, T.; Tánczos, B.; Farkas, R.; et al. First molecular evidence of Anaplasma ovis and Rickettsia spp. in keds (Diptera: Hippoboscidae) of sheep and wild ruminants. Vector. Borne. Zoonotic. Dis. 2011, 11, 1319-1321. [CrossRef] [PubMed]

14. Hornok, S.; Hofmann-Lehmann, R.; de Mera, I.G.; Meli, M.L.; Elek, V.; Hajtós, I.; Répási, A.; Gönczi, E.; Tánczos, B.; Farkas, R.; et al. Survey on blood-sucking lice (Phthiraptera: Anoplura) of ruminants and pigs with molecular detection of Anaplasma and Rickettsia spp. Vet. Parasitol. 2010, 174, 355-358. [CrossRef]

15. Sunantaraporn, S.; Sanprasert, V.; Pengsakul, T.; Phumee, A.; Boonserm, R.; Tawatsin, A.; Thavara, U.; Siriyasatien, P. Molecular survey of the head louse Pediculus humanus capitis in Thailand and its potential role for transmitting Acinetobacter spp. Parasit. Vectors 2015, 8, 127. [CrossRef]

16. Furman, D.P.; Catts, E.P. Manual of Medical Entomology, 4th ed.; Cambridge University Press: Cambridge, UK, 1982.

17. Price, M.A.; Graham, O.H. Chewing and Sucking Lice as Parasites of Mammals and Birds; U.S. Dept. of Agriculture, Agricultural Research Service: Washington, DC, USA, 1997; Volume 1849.

18. Norman, A.F.; Regnery, R.; Jameson, P.; Greene, C.; Krause, D.C. Differentiation of Bartonella-like isolates at the species level by PCR-restriction fragment length polymorphism in the citrate synthase gene. J. Clin. Microbiol. 1995, 33, 1797-1803. [PubMed] 
19. Kempf, M.; Abdissa, A.; Diatta, G.; Trape, J.F.; Angelakis, E.; Mediannikov, O.; La Scola, B.; Raoult, D. Detection of Acinetobacter baumannii in human head and body lice from Ethiopia and identification of new genotypes. Int. J. Infect. Dis. 2012, 16, e680-e683. [CrossRef]

20. Rolain, J.M.; Stuhl, L.; Maurin, M.; Raoult, D. Evaluation of antibiotic susceptibilities of three rickettsial species including Rickettsia felis by a quantitative PCR DNA assay. Antimicrob. Agents. Chemother. 2002, 46, 2747-2751. [CrossRef]

21. Oksi, J.; Rantala, S.; Kilpinen, S.; Silvennoinen, R.; Vornanen, M.; Veikkolainen, V.; Eerola, E.; Pulliainen, A.T. Cat scratch disease caused by Bartonella grahamii in an immunocompromised patient. J. Clin. Microbiol. 2013, 51, 2781-2784. [CrossRef]

22. Hall, T.A. BioEdit: A user-friendly biological sequence alignment editor and analysis program for Windows 95/98/NT. Nucleic Acids Symp. Ser. 1999, 41, 95-98.

23. Trifinopoulos, J.; Nguyen, L.T.; von Haeseler, A.; Minh, B.Q. W-IQ-TREE: A fast online phylogenetic tool for maximum likelihood analysis. Nucleic Acids Res. 2016, 44, W232-W235. [CrossRef]

24. Wang, Y.; Engel, M.S.; Rafael, J.A.; Dang, K.; Wu, H.; Wang, Y.; Xie, Q.; Bu, W. Correction: A Unique Box in $28 \mathrm{~S}$ rRNA Is Shared by the Enigmatic Insect Order Zoraptera and Dictyoptera. PLoS ONE 2013, 8, e53679. [CrossRef]

25. Yoshizawa, K.; Johnson, K.P. How stable is the "Polyphyly of Lice" hypothesis (Insecta: Psocodea)? A comparison of phylogenetic signal in multiple genes. Mol. Phylogenet. Evol. 2010, 55, 939-951. [CrossRef] [PubMed]

26. Light, J.E.; Smith, V.S.; Allen, J.M.; Durden, L.A.; Reed, D.L. Evolutionary history of mammalian sucking lice (Phthiraptera: Anoplura). BMC Evol. Biol. 2010, 10, 292. [CrossRef]

27. Barker, S.C.; Whiting, M.; Johnson, K.P.; Murrell, A. Phylogeny of the lice (Insecta, Phthiraptera) inferred from small subunit rRNA. Zool. Scripta 2003, 32, 407-414. [CrossRef]

28. Kho, K.L.; Koh, F.X.; Jaafar, T.; Nizam, Q.N.; Tay, S.T. Prevalence and molecular heterogeneity of Bartonella bovis in cattle and Haemaphysalis bispinosa ticks in Peninsular Malaysia. BMC Vet. Res. 2015, 11, 153. [CrossRef]

29. Bai, Y.; Malania, L.; Alvarez Castillo, D.; Moran, D.; Boonmar, S.; Chanlun, A.; Suksawat, F.; Maruyama, S.; Knobel, D.; Kosoy, M. Global distribution of Bartonella infections in domestic bovine and characterization of Bartonella bovis strains using multilocus sequence typing. PLoS ONE 2013, 8, e80894. [CrossRef]

30. Kosoy, M.; Hayman, D.T.; Chan, K.S. Bartonella bacteria in nature: Where does population variability end and a species start? Infect. Genet. Evol. 2012, 12, 894-904. [CrossRef]

31. Cheslock, M.A.; Embers, M.E. Human Bartonellosis: An Underappreciated Public Health Problem? Trop. Med. Infect. Dis. 2019, 4, 69. [CrossRef]

32. Pulliainen, A.T.; Dehio, C. Persistence of Bartonella spp. stealth pathogens: From subclinical infections tovasoproliferative tumor formation. FEMS Microbiol. Rev. 2012, 36, 563-599. [CrossRef]

33. Seki, N.; Kasai, S.; Saito, N.; Komagata, O.; Mihara, M.; Sasaki, T.; Tomita, T.; Sasaki, T.; Kobayashi, M. Quantitative analysis of proliferation and excretion of Bartonella quintana in body lice, Pediculus humanus L. Am. J. Trop. Med. Hyg. 2007, 77, 562-566. [CrossRef] [PubMed]

34. Jiyipong, T.; Jittapalapong, S.; Morand, S.; Raoult, D.; Rolain, J.M. Prevalence and genetic diversity of Bartonella spp. in small mammals from Southeastern Asia. Appl. Environ. Microbiol. 2012, 78, 8463-8466. [CrossRef] [PubMed]

35. Watt, G.; Pachirat, O.; Baggett, H.; Maloney, S.; Lulitanond, V.; Raoult, D.; Bhengsri, S.; Thamthitiwat, S.; Paupairoj, A.; Kosoy, M.; et al. Infective Endocarditis in Northeastern Thailand. Emerg. Infect. Dis. 2014, 20, 473-476. [CrossRef]

36. Kosoy, M.; Bai, Y.; Sheff, K.; Morway, C.; Baggett, H.; Maloney, S.A.; Boonmar, S.; Bhengsri, S.; Dowell, S.F.; Sitdhirasdr, A.; et al. Identification of Bartonella infections in febrile human patients from Thailand and their potential animal reservoirs. Am. J. Trop. Med. Hyg. 2010, 82, 1140-1145. [CrossRef]

37. Martini, M.; Menandro, M.L.; Mondin, A.; Pasotto, D.; Mazzariol, S.; Lauzi, S.; Stelletta, C. Detection of Bartonella bovis in a cattle herd in Italy. Vet. Rec. 2008, 162, 58-59. [CrossRef] 
38. Maillard, R.; Grimard, B.; Chastant-Maillard, S.; Chomel, B.; Delcroix, T.; Gandoin, C.; Bouillin, C.; Halos, L.; Vayssier-Taussat, M.; Boulouis, H.J. Effects of cow age and pregnancy on Bartonella infection in a herd of dairy cattle. J. Clin. Microbiol. 2006, 44, 42-46. [CrossRef]

39. Welc-Faleciak, R.; Grono, K. The first cases of Bartonella bovis infection in cattle from Central Europe. Vet. Microbiol. 2013, 162, 954-956. [CrossRef]

40. Cherry, N.A.; Maggi, R.G.; Cannedy, A.L.; Breitschwerdt, E.B. PCR detection of Bartonella bovis and Bartonella henselae in the blood of beef cattle. Vet. Microbiol. 2009, 135, 308-312. [CrossRef]

41. Diaz, M.H.; Bai, Y.; Malania, L.; Winchell, J.M.; Kosoy, M.Y. Development of a novel genus-specific real-time PCR assay for detection and differentiation of Bartonella species and genotypes. J. Clin. Microbiol. 2012, 50, 1645-1649. [CrossRef]

(C) 2019 by the authors. Licensee MDPI, Basel, Switzerland. This article is an open access article distributed under the terms and conditions of the Creative Commons Attribution (CC BY) license (http://creativecommons.org/licenses/by/4.0/). 